Article

\title{
Self-Healing Biogeopolymers Using Biochar-Immobilized Spores of Pure- and Co-Cultures of Bacteria
}

\author{
Jadin Zam S. Doctolero ${ }^{1} \mathbb{D}$, Arnel B. Beltran ${ }^{1,2}{ }^{\text {, Marigold O. } \mathrm{Uba}^{3}{ }^{3} \text {, April Anne S. Tigue }}{ }^{1}$ \\ and Michael Angelo B. Promentilla 1,2,*(D) \\ 1 Chemical Engineering Department, Gokongwei College of Engineering, De La Salle University, \\ Manila 1004, Philippines; jadin_doctolero@dlsu.edu.ph (J.Z.S.D.); arnel.beltran@dlsu.edu.ph (A.B.B.); \\ april_tigue@dlsu.edu.ph (A.A.S.T.) \\ 2 Center for Engineering and Sustainable Development Research, De La Salle University, \\ Manila 1004, Philippines \\ 3 Biology Department, College of Science, De La Salle University, Manila 1004, Philippines; \\ marigold.uba@dlsu.edu.ph \\ * Correspondence: michael.promentilla@dlsu.edu.ph; Tel.: +63-02-536-0223
}

Received: 7 November 2020; Accepted: 9 December 2020; Published: 11 December 2020

\begin{abstract}
A sustainable solution for crack maintenance in geopolymers is necessary if they are to be the future of modern green construction. This study aims to develop self-healing biogeopolymers that could potentially rival bioconcrete. First, a suitable healing agent was selected from Bacillus subtilis, Bacillus sphaericus, and Bacillus megaterium by directly adding their spores in the geopolymers and subsequently exposing them to a precipitation medium for 14 days. Scanning electron microscope with energy-dispersive X-ray (SEM-EDX) analysis revealed the formation of mineral phases for B. subtilis and B. sphaericus. Next, the effect of biochar-immobilization and co-culturing (B. sphaericus and $B$. thuringiensis) on the healing efficiencies of the geopolymers were tested and optimized by measuring their ultrasonic pulse velocities weekly over a 28-day healing period. The results show that using co-cultured bacteria significantly improved the observed efficiencies, while biochar-immobilization had a weak effect, but yielded an optimum response between $0.3-0.4 \mathrm{~g} / \mathrm{mL}$. The maximum crack width sealed was $0.65 \mathrm{~mm}$. Through SEM-EDX and FTIR analyses, the precipitates in the cracks were identified to be mainly $\mathrm{CaCO}_{3}$. With that, there is potential in developing self-healing biogeopolymers using biochar-immobilized spores of bacterial cultures.
\end{abstract}

Keywords: geopolymer; biogeopolymer; self-healing; crack repair; microbially induced calcite precipitation; ureolytic bacteria; non-ureolytic bacteria; co-cultured bacteria

\section{Introduction}

Geopolymers have become a promising greener alternative to concrete, due to their low carbon footprint and excellent mechanical, and chemical properties. They can be produced from a reaction involving an aluminosilicate source, which can come from waste byproducts like coal fly ash, and an alkaline solution that can induce the geopolymerization process. The use of different precursors and mix ratios has enabled several studies to report notable properties like high compressive/flexural strength, low shrinkage, acid and fire resistance, and high temperature and chemical stability in geopolymers [1-4]. However, being a cementitious material like concrete, they are still vulnerable to crack formation. This is undesirable, as it can cause the loss of structural integrity when geopolymers are used as materials of construction. 
The traditional methods to repair cracks are often complex, expensive, and labor-intensive [5]. They can even be especially difficult to accomplish in hard-to-reach areas. Moreover, they must be addressed as soon as they form to prevent further crack propagation. For this reason, self-healing has evolved as a promising solution to these problems. Past studies often favor using non-pathogenic soil microorganisms as healing agents because they are potentially safer and more sustainable than using chemical-based ones [6].

Bio-based self-healing occurs because when cracks form, air and water can reach the dormant microbes, activate them, and cause them to precipitate minerals, which then seal the cracks [5-7]. This phenomenon may be the result of biologically induced or controlled mineralization depending on the species or agents used [8]. For biologically induced mineralization, minerals are produced, due to the metabolic activities of the microorganisms, and the chemical reactions associated with the metabolic byproducts [9]. Its disadvantages are the poor crystallinity of the minerals, the inclusion of impurities in their lattice structure, and the lack of control over mineral formation [10]. On the other hand, for biologically controlled mineralization, the microorganisms exert more control in crystal formation, due to the direct synthesis of the crystals at specific locations, yielding better crystalline structures [9]. However, it is through induced mineralization in which more precipitates could be often produced in shorter periods of time [9].

By harnessing the potential of induced mineralization, huge progress has already been made for bio-based self-healing in cementitious materials, giving rise to bioconcrete [9,11-14]. Bacillus bacteria are often employed because of their well-studied ability to form endospores and cause precipitation of minerals. Despite these advancements, little is known whether the same methods used to make bioconcrete can also work for a geopolymer, which inherently has a different physicochemical structure. It can also be more deleterious for microbial growth. At present, very few studies exist that explore using microorganisms in geopolymers for self-healing applications and enhancement of mechanical properties. Related studies are summarized in Table 1.

Table 1. Related studies on microbial applications on geopolymers.

\begin{tabular}{|c|c|c|c|c|}
\hline Geopolymer Precursor & Healing Agent & Key Findings & Year of Publication & Reference \\
\hline Metakaolin & Sporosarcinapasteurii & $\begin{array}{l}\text { Sealing of } 89 \pm 3-\mu \mathrm{m} \text { crack widths with } \\
\qquad \mathrm{CaCO}_{3}\end{array}$ & 2018 & [15] \\
\hline Fly Ash & $\begin{array}{l}\text { Solution of } S \text {. } \\
\text { pasteurii and yeast } \\
\text { from a fungi }\end{array}$ & $\begin{array}{l}\text { Geopolymer pores were filled with } \\
\mathrm{CaCO}_{3} \text {, causing improvements in their } \\
\text { mechanical properties }\end{array}$ & 2018 & [16] \\
\hline Fly Ash & $\begin{array}{l}\text { Genetically-modified } \\
\text { B. subtilis }\end{array}$ & $\begin{array}{c}70.9 \%, 40.0 \% \text {, and } 68.87 \% \text { increase in } \\
\text { compressive strength, ultrasonic pulse } \\
\text { velocity, and acid resistance, respectively, } \\
\text { after } 28 \text { days }\end{array}$ & 2019 & [17] \\
\hline Fly Ash & $\begin{array}{c}\text { Solution of } S . \\
\text { pasteurii and } \\
\text { Rhizopus oligosporus }\end{array}$ & $\begin{array}{l}43.75 \% \text { increase in compressive strength; } \\
\text { higher amount of closed porosity for all } \\
\text { specimens with microbes }\end{array}$ & 2021 & [18] \\
\hline
\end{tabular}

Given the huge gap that needs to be filled in truly developing self-healing biogeopolymers, the present study seeks to explore what locally available species of bacteria can be used as healing agents for fly ash-based geopolymers and how their viability in such material can be further improved. The two factors that were tested to improve bacterial viability are immobilization and co-culturing.

Immobilization of bacteria spores before adding them to a concrete mixture has been reported to increase the survivability of bacteria in a cementitious matrix over a longer period of time [5]. This is because of the additional layer that serves as protection from external stresses, such as the mechanical strains during mixing. A study mentions that biochar has the potential to be used as an immobilizer because of its pore structure, which can house the bacteria spores, and its high affinity for fluid absorption and retention [13].

As for co-culturing, it was reported that a ureolytic bacteria and a non-ureolytic one can synergize to boost the precipitation of $\mathrm{CaCO}_{3}$ [19]. This is due to the surface of the non-ureolytic bacterial cells 
acting as additional nucleation sites for the $\mathrm{Ca}^{2+}$ ions to combine with $\mathrm{CO}_{3}{ }^{2-}$. In addition, it was also observed that the combined respiration rate of the two bacteria species reduced the alkalinity of the environment they were in. As a result, their viability in concrete greatly improved.

To the best of the authors' knowledge, immobilization and co-culturing bacteria have not been tested yet in developing self-healing geopolymers using microorganisms. With that, the present study finds relevance in building on a potential method to synthesize self-healing biogeopolymers.

\section{Materials and Methods}

\subsection{Materials}

The bacteria used to screen a suitable healing agent were B. subtilis BIOTECH 1679, B. sphaericus BIOTECH 1272, and B. megaterium BIOTECH 1512. The non-ureolytic species used for making the co-cultures was B. thuringiensis BIOTECH 1092. These bacteria were obtained from the Philippine National Collection of Microorganisms in Laguna, Philippines.

The geopolymer precursor employed was class F coal fly ash (FA) that was obtained from a coal-fired power plant in Bataan, Philippines. The alkaline activator (AA) was a constant mixture of $\mathrm{Na}_{2} \mathrm{SiO}_{3}$ and $12 \mathrm{M} \mathrm{NaOH}$ at a mass ratio of 2.5. The immobilizer utilized was rice-husk biochar, which was obtained from the Philippine Rice Research Institute.

\subsection{Equipment}

The main equipment used were the scanning electron microscope with energy-dispersive $x$-ray (SEM-EDX, Dual Beam Helios Nanolab 600i, FEI, Hillsboro, OR, USA) at FESEM accelerating voltage of $5.0 \mathrm{kV}$, FESEM beam current of $0.17 \mathrm{nA}$, EDS accelerating voltage of $15.0 \mathrm{kV}$, and EDS beam current of $0.69 \mathrm{nA}$; X-ray diffractometer (XRD, Multiflex Rigaku Automated Powder XRD, Rigaku Corporation, Tokyo, Japan); X-ray fluorescence spectrophotometer (XRF, Shimadzu Model EDX-720, Shimadzu Corporation, Kyoto, Japan); attenuated total reflectance Fourier-transform infrared spectrometer (FTIR, Perkin Elmer Frontier 100, Perkin Elmer, Waltham, MA, USA); and ultrasonic pulse velocity equipment using $150 \mathrm{kHz}$ transducers (UPV, Pundit Lab+ CT-133, Proceq, Schwerzenbach, Switzerland).

\subsection{Methods}

\subsubsection{Initial Characterization}

The fly ash was first sieved using a 2-mm sieve screen to remove the large particles. After which, information regarding its elemental and mineral composition was obtained using energy-dispersive XRF and XRD. This is shown in Figure 1. Given the percent composition of silicon and aluminum in the table, the fly ash used could be considered a good aluminosilicate precursor for geopolymerization. Meanwhile, the XRD analysis indicates that quartz $\left(\mathrm{SiO}_{2}\right)$, mullite $\left(3 \mathrm{Al}_{2} \mathrm{O}_{3} \cdot 2 \mathrm{SiO}_{2}\right)$, hematite $\left(\mathrm{Fe}_{2} \mathrm{O}_{3}\right)$, and magnetite $\left(\mathrm{Fe}_{3} \mathrm{O}_{4}\right)$ were present in the fly ash.

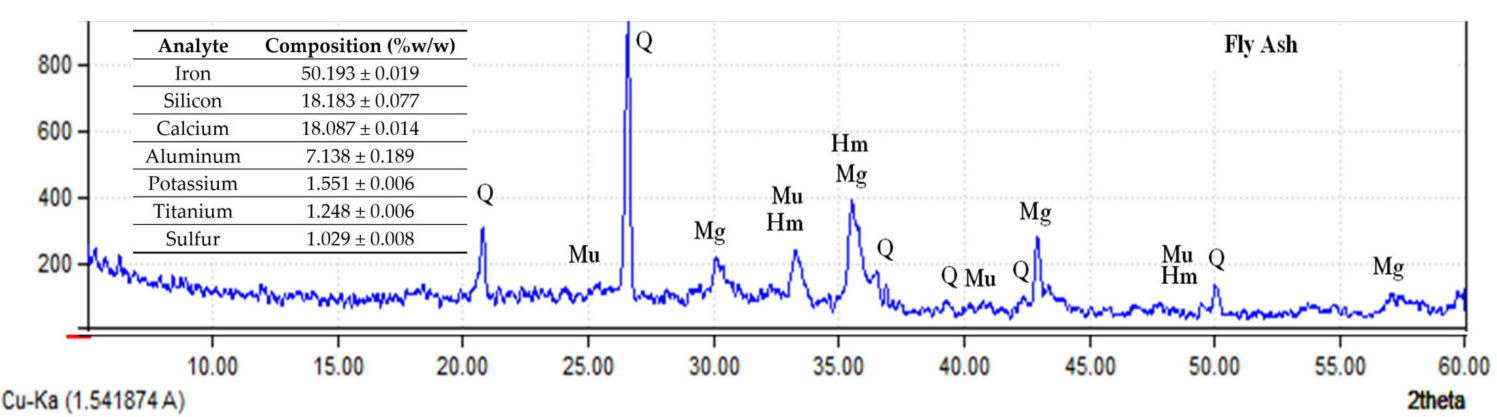

Figure 1. Elemental and mineral composition of the coal fly ash. 
The biochar was also analyzed in terms of its morphology and elemental composition via SEM-EDX. This is presented in Figure 2. Its pore structure is evident, which is beneficial for effectively housing and protecting the bacteria spores from external stresses. The pores were measured to be around 4.5-9.1 $\mu \mathrm{m}$, which is bigger than the typical size of the Bacillus spores (around 1-2 $\mu \mathrm{m}$ ). The biochar pores are also advantageous for holding water, one of the main requirements for promoting bacterial viability. As for its elemental composition, it is mainly rich in carbon, as the process of pyrolysis typically leaves behind a carbon-rich residue.

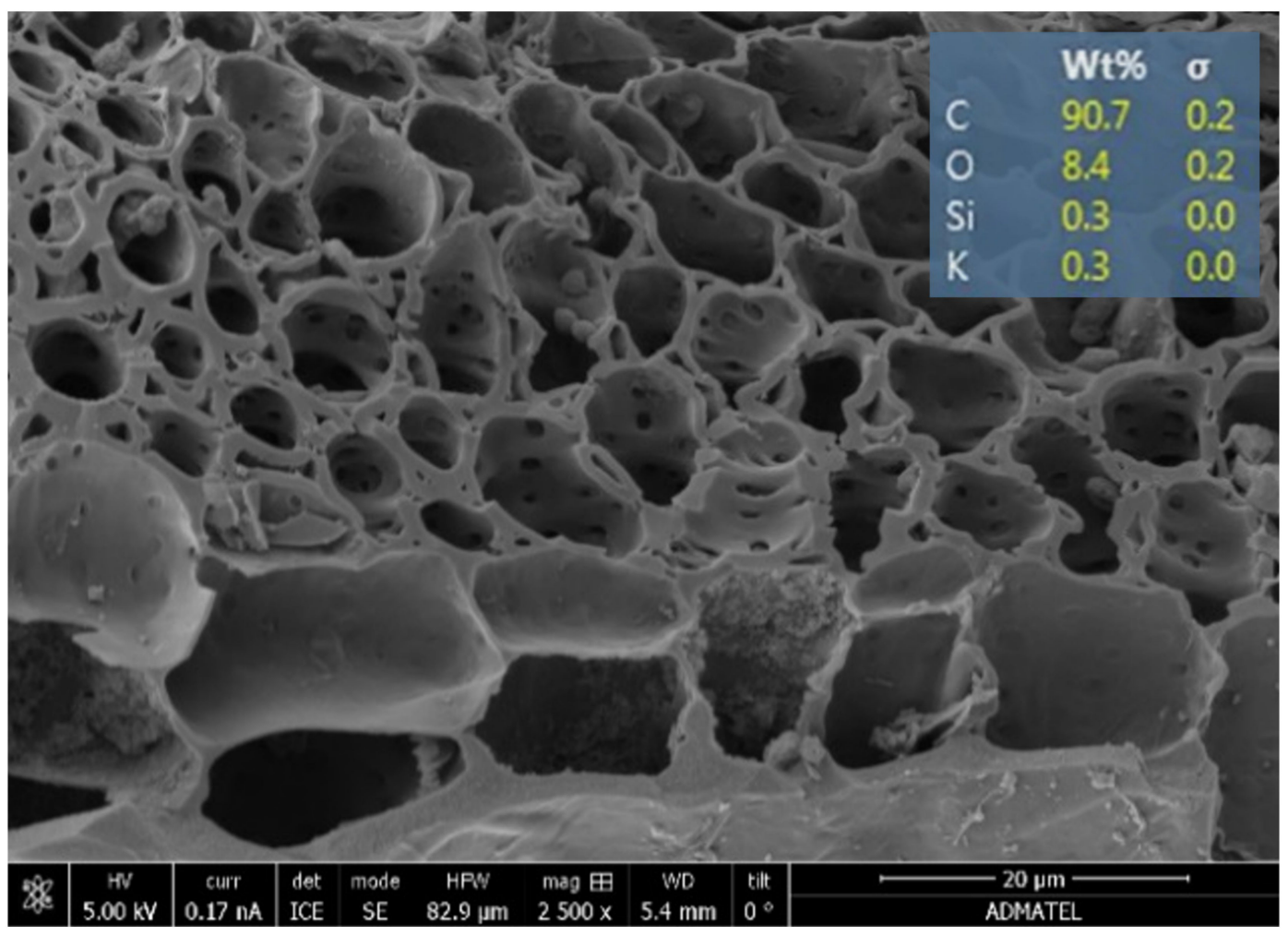

Figure 2. SEM-EDX analysis of biochar at $2500 \times$ magnification.

\subsubsection{Preparation of Spore Suspensions}

The spore suspensions of B. subtilis, B. sphaericus, and B. megaterium were made by first culturing them in separate sporulation mediums ( $13 \mathrm{~g} / \mathrm{L}$ nutrient broth solutions with $10 \mathrm{mg} / \mathrm{L}$ of $\mathrm{MnSO}_{4} \cdot \mathrm{H}_{2} \mathrm{O}$ ) at $35^{\circ} \mathrm{C}$ and $100 \mathrm{rpm}$ agitation in a shaker bath for 7 days. After which, the broths were subjected to a heat shock treatment. This involved sudden immersion at $80^{\circ} \mathrm{C}$ for $10 \mathrm{~min}$ followed by immediate cooling in an ice-water bath for $5 \mathrm{~min}$. Next, the spores were harvested at $6000 \mathrm{rpm}$ for $15 \mathrm{~min}$ using a centrifuge. The spores were then washed twice with isotonic saline solution. From the spores collected, the spore suspensions (optical density of 2.0 at $600-\mathrm{nm}$ setting) were made. These were subsequently pasteurized at $80^{\circ} \mathrm{C}$ for $20 \mathrm{~min}$ before storing them at $4{ }^{\circ} \mathrm{C}$. The Schaeffer-Fulton method was used to verify spore formation, and the stain results are shown in the Appendix B.

\subsubsection{Selection of a Suitable Healing Agent}

The geopolymer mixture was first made by mixing AA and FA at a mass ratio of 0.39 . After thorough mixing, $6 \mathrm{~mL}$ of one of the three pre-prepared spore suspensions was added for every $95 \mathrm{~g}$ of AA used. These ratios were based on modifications of previous studies done on optimal geopolymer mix ratios for workability and compressive strength [20], and on making self-healing concrete [21]. The resulting mixture was then cast into the 50-mm cubic molds. Control specimens were also created. For these geopolymers, distilled water was added instead of a spore suspension. 
Once the cubes had partially hardened, a 1-mm width slice was made at the top to simulate a single 1-mm crack. After $24 \mathrm{~h}$, the cubes were demolded and immersed in a precipitation medium $\left(38.5 \mathrm{~g} / \mathrm{L}\right.$ urea broth and $\left.5.6 \mathrm{~g} / \mathrm{L} \mathrm{CaCl}_{2}\right)$ for 14 days. From the results, only one suitable healing agent was selected for use in the two-factor test.

\subsubsection{Two-Factor Test on Immobilization and Co-Culturing}

The two factors tested in this phase were the type of culture (pure culture vs. co-culture) and the concentration of the biochar in the spore suspensions (low level of $0 \mathrm{~g} / \mathrm{mL}$ and high level of $0.70 \mathrm{~g} / \mathrm{mL}$ ). Design-Expert ${ }^{\circledR}(\mathrm{V} 11)$ was used to generate the experimental design involving a categorical factor and a numerical factor. This is presented in the Appendix A. Essentially, the bacteria-containing geopolymers were composed of fly ash, activator, spore suspension with or without biochar, and nutrient solution. For the control specimens, the only difference was that distilled water was used instead of the spore suspensions.

To prepare the co-cultures, $B$. thuringiensis was grown together with the previously selected healing agent in the same sporulation medium [19]. The same methods discussed in Section 2.3.2 were then applied to make the spore suspensions. To immobilize the spores, biochar was added to the suspensions, and the mixtures were placed in an orbital shaker for $1 \mathrm{~h}$ at $140 \mathrm{rpm}$ to allow sufficient soaking [13]. As for the nutrient solutions, these were made by supplementing $20 \mathrm{~g} / \mathrm{L}$ of urea and $5.6 \mathrm{~g} / \mathrm{L}$ of $\mathrm{CaCl}_{2}$ to the nutrient broth.

Following the preparation of the suspensions and nutrient solutions, the geopolymers were made using the same mix ratios in Section 2.3.3. The nutrient solution was added last to the mixture. The mixtures were then cast into $50-\mathrm{mm}$ cubic molds. There were three replicates for every treatment/control group. After $24 \mathrm{~h}$, the cubes were demolded and subjected to oven curing at $60^{\circ} \mathrm{C}$ for 1 day to induce more natural cracks via thermal stress. This was then followed by six days of ambient curing (average temperature of $30^{\circ} \mathrm{C}$ ) by leaving the specimens exposed to open air.

Afterward, the geopolymers were subjected to a dry-wet cycle ( $20 \mathrm{~h}$ underwater and $4 \mathrm{~h}$ air-drying) for 14 days and complete water immersion for the next 14 days. To non-destructively measure the changes in the geopolymers' mechanical properties, UPV measurements (using 150-kHz transducers) were taken every 7 days for the duration of the 28-day healing period.

\subsubsection{Characterization of the Geopolymers and the Mineral Precipitates}

Finally, material characterization studies were performed. FTIR analysis was first done on the fly ash and a geopolymer specimen. Then, SEM-EDX and FTIR analyses were carried out to check for the presence of mineral phases in the collected precipitates from the geopolymer cracks and to determine their possible composition.

\section{Results and Discussion}

\subsection{A Suitable Healing Agent for Geopolymers}

The geopolymers with B. subtilis, B. sphaericus, and B. megaterium were observed after 14 days of immersion in the precipitation medium to select a suitable healing agent that could be used. It was observed that all those geopolymers exhibited no sealing of the induced cracks. However, upon closer inspection using an optical microscope, trace amounts of mineral-like structures were observed on the crack surfaces of the geopolymers with B. subtilis and B. sphaericus. At $10,000 \times$ magnification using an SEM, the presence of crystalline structures that were beginning to form were found. This could be attributed to the bacteria's cellular metabolism affecting the extracellular solution, leading to mineral precipitation [7-9]. The EDX analysis is shown in Figure 3. Due to the insufficient production of precipitates in the geopolymer cracks at this stage of the research, a proper analysis could not be performed to verify their true identities or composition. Nonetheless, there is initial evidence that bacterially induced mineralization has occurred for the geopolymers with B. subtilis and B. sphaericus. 

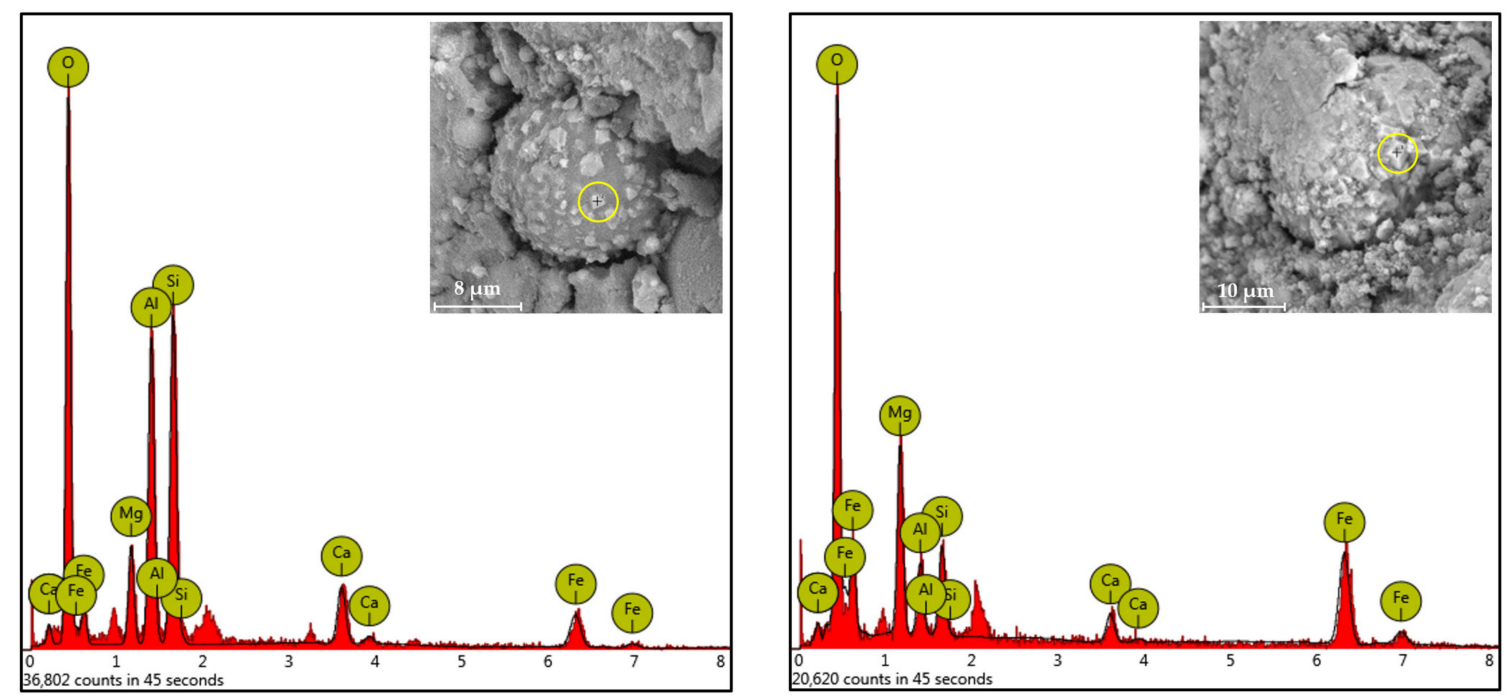

Figure 3. EDX analysis of the mineral phases on the geopolymer with (a) B. subtilis; (b) B. sphaericus.

For this study, only one healing agent from B. subtilis or B. sphaericus could be further tested. For the succeeding two-factor test, $B$. sphaericus was the selected bacteria, as it has been mentioned in a previous study that it performs significantly better than B. subtilis in improving a material's mechanical properties [22].

\subsection{Effect of Biochar-Immobilization and Co-Culturing}

\subsubsection{Test Results for the Control Geopolymers}

The results for the control geopolymers are presented first to serve as a point of comparison for the findings for the bacteria-containing geopolymers. Through physical inspection of the control specimens, no precipitates were found that sealed the induced cracks. The changes in their mechanical properties were obtained next by comparing their UPV after cracking, but before the healing period and after 28 healing days. UPVs work as a non-destructive measure of a material's quality by allowing ultrasonic waves to pass through it. The faster these waves travel, which happens when there are fewer cracks or voids in the material, the better the quality of the specimen.

The obtained mean healing efficiencies (percent improvement from the initial UPV after 28 healing days) are summarized in Table 2. It can be seen that the control specimens underwent an improvement of $2-3 \%$ despite the absence of bacteria. This could be attributed to the ongoing geopolymerization within the specimens even after curing for a total of 7 days. The same phenomenon could actually be also observed in concrete, wherein the hydration reactions continue to strengthen the material for roughly 28 days. Despite the limited curing time of the geopolymers, which resulted in the observed healing efficiencies in Table 2, the data for the bacteria-containing specimens can still be justified by considering the largest improvement of $2.70 \%$ as the limit for which "healing" is only due to the ongoing geopolymerization.

Table 2. Healing efficiencies of the control geopolymers based on UPV measurements.

\begin{tabular}{ccc}
\hline Control Group & Biochar Concentration $(\mathrm{g} / \mathrm{mL})$ & Mean Healing Efficiency $(\%)$ \\
\hline Con-A & 0 & 2.12 \\
\hline Con-B & 0.175 & 2.33 \\
\hline Con-C & 0.525 & 2.70 \\
\hline Con-D & 0.7 & 2.61 \\
\hline
\end{tabular}




\subsubsection{Test Results for the Bacteria-Containing Geopolymers}

Physical inspection of the bacteria-containing geopolymers after 28 healing days provided a completely different result than the one observed for the control groups. It was observed that all the bacteria-containing geopolymers exhibited crack closures, albeit to varying degrees. Figure 4 shows the precipitates in the cracks for the representative geopolymers with pure- and co-cultures of bacteria. The physical characteristics of the precipitates differed from the efflorescence products on the surface of the geopolymers; thus, they are likely to have materialized, due to bacterially induced mineralization.

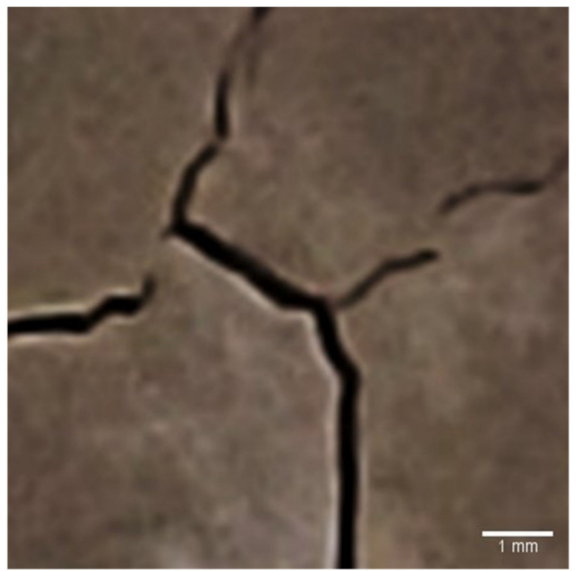

(a)

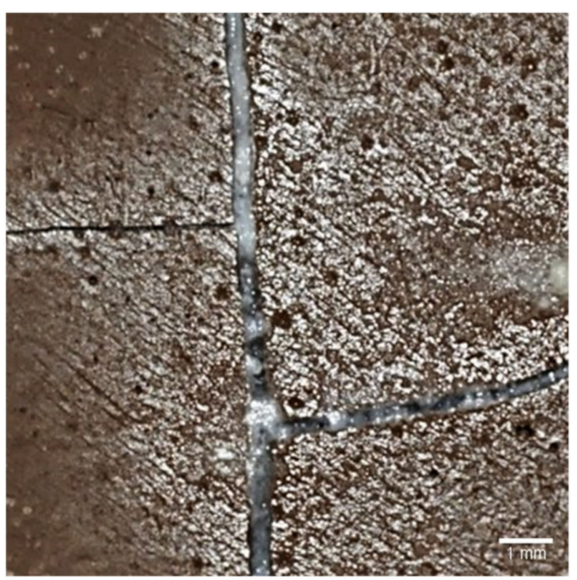

(c)

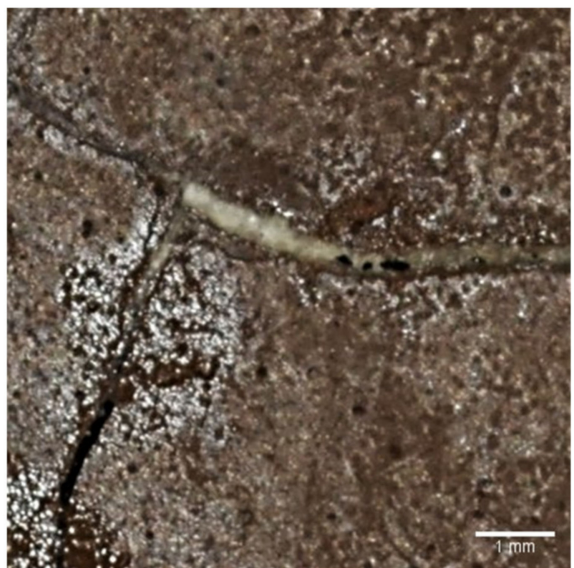

(b)

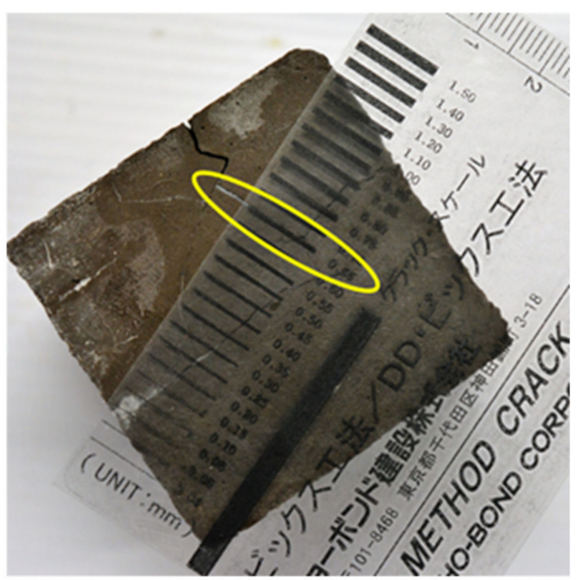

(d)

Figure 4. Crack sealing in a geopolymer after 28 healing days: (a) Control specimen; (b) using pure culture; (c) using co-culture; (d) maximum crack width sealed.

For the geopolymers with co-cultures, sealing of crack widths ranging from $0.10 \mathrm{~mm}$ to $0.65 \mathrm{~mm}$ were observed, while for those with pure cultures, it was only up to $0.35 \mathrm{~mm}$. With this observation, the use of co-cultures can be said to be more effective based on solely crack sealing.

When cracks in a cementitious material are sealed, their continuity naturally improves, giving rise to the observed strength developments over time. This is because the air gaps in it are gradually replaced with solid materials, leading to a greater compaction. The more compact the test specimen, the higher is the expected UPV value and quality of the material. UPV measurements were, thus, used to non-destructively describe the restoration of the lost mechanical properties. The healing efficiencies were obtained similarly with the control specimens as previously discussed. This can be found in Table 3. 
Table 3. Healing efficiencies of the bacteria-containing geopolymers based on UPV measurements.

\begin{tabular}{cccc}
\hline Run & Biochar Concentration $(\mathbf{g} / \mathbf{m L})$ & Type of Culture & Mean Healing Efficiency $(\%)$ \\
\hline 1 & 0 & Pure Culture & 7.15 \\
\hline 10 & 0.0945 & Pure Culture & 7.38 \\
\hline 4 & 0.35 & Pure Culture & 7.55 \\
\hline 7 & 0.35 & Pure Culture & 7.75 \\
\hline 9 & 0.35 & Pure Culture & 7.91 \\
\hline 6 & 0.6055 & Pure Culture & 7.91 \\
\hline 3 & 0.7 & Pure Culture & 7.51 \\
\hline 8 & 0 & Co-Culture & 9.97 \\
\hline 13 & 0 & Co-Culture & 7.61 \\
\hline 2 & 0.175 & Co-Culture & 13.23 \\
\hline 5 & 0.35 & Co-Culture & 12.30 \\
\hline 14 & 0.35 & Co-Culture & 10.30 \\
\hline 11 & 0.525 & Co-Culture & 11.21 \\
\hline 12 & 0.7 & Co-Culture & 9.79 \\
\hline 15 & 0.7 & Co-Culture & 7.83 \\
\hline
\end{tabular}

A summary of the mean healing efficiencies in Table 3 is shown in Figure 5. The red points indicate the efficiencies for the geopolymers with pure cultures, while the green ones are for those with co-cultures. The dashed lines indicate the $95 \%$ confidence interval. The statistical analysis for this model and for the two-factor test results is presented in the Appendix C.

It can be seen from Figure 5 that changing the type of culture used caused the healing efficiencies to considerably increase. This can be easily visualized by looking at the green curve above the red one. Moreover, the statistical analysis points out that it has a $p$-value way lower than 0.05 , making it highly significant. This supports the previous study done showing that co-culturing ureolytic and non-ureolytic bacteria has a synergistic effect on their mineralization activity [19].

Changing the biochar concentration, on the other hand, yielded a $p$-value above 0.05 , making it insignificant. Thus, increasing the amount of biochar used to immobilize a given volume of spore suspension did not strongly contribute to the changes in the healing efficiencies of the geopolymers. However, looking at Figure 5, minor rises could still be observed in the healing efficiencies upon increasing the biochar loading. The response peaks at a certain point, then it decreases upon further loading. A possible explanation for this behavior is that the biochar initially serves as an additional protective layer for the spores, thereby increasing their viability in the geopolymers and causing the healing efficiencies to increase. It was also noted by a similar study that using a carrier material like biochar can aid in the distribution of spores within a specimen, ensuring the availability of bacteria spores at a crack site [13]. However, at higher biochar concentrations, their cellular metabolism could have been adversely affected by the increased interaction of the biochar with the microbes [23]. This could be further explored in future studies.

For both factors considered, the healing efficiencies obtained were well above the limit established from the results gathered from the control geopolymers. Therefore, the observed improvements in the properties of the bacteria-containing geopolymers arose because of bacterially induced mineralization and not from the ongoing geopolymerization. Optimization of the two factors yielded a maximum healing efficiency of $11.37 \%$ using $0.33 \mathrm{~g} / \mathrm{mL}$ of biochar and co-cultured bacteria. The solutions are illustrated in Figure 6. 

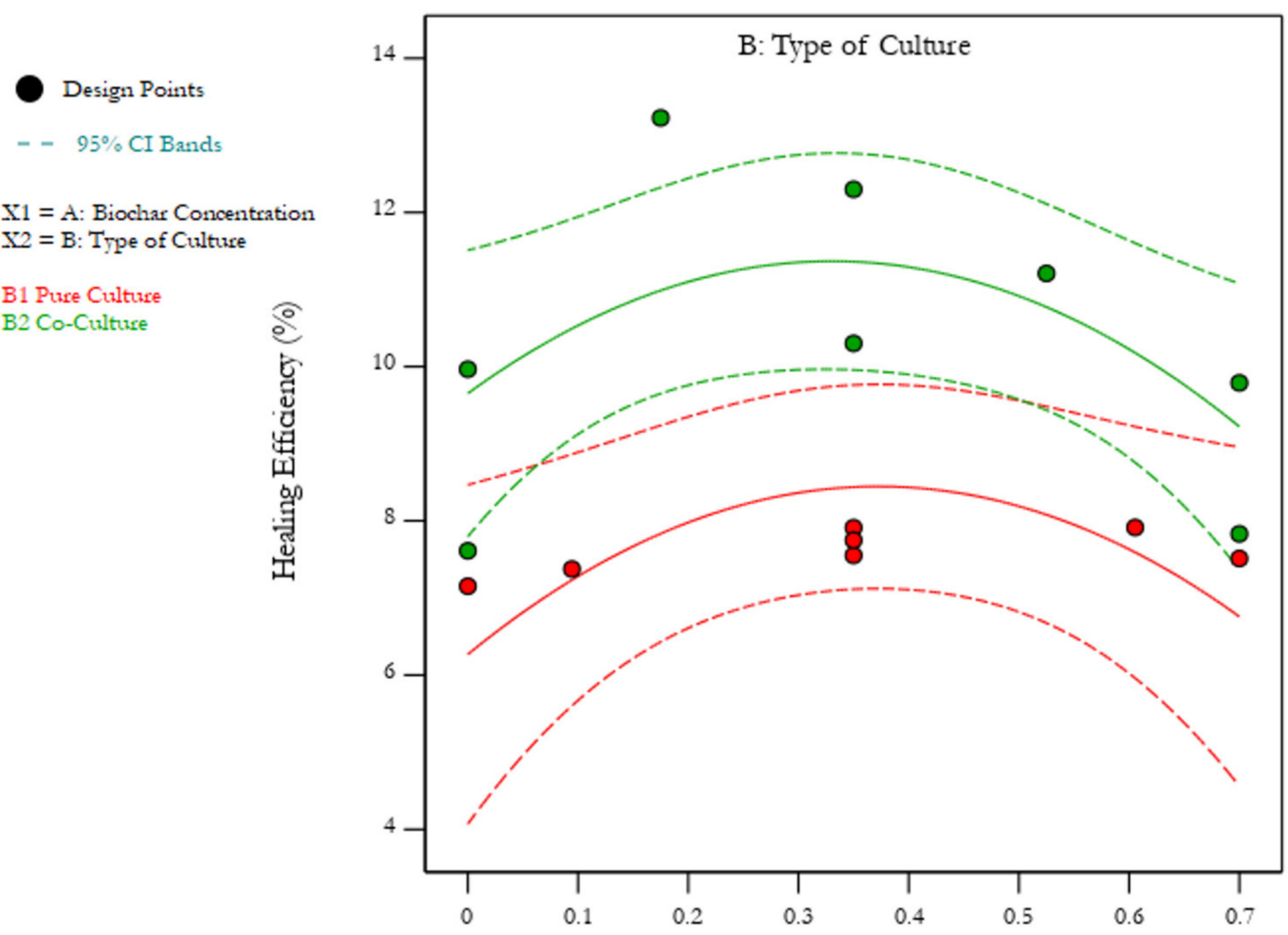

A: Biochar Concentration $(\mathrm{g} / \mathrm{mL})$

Figure 5. Graphical model on the effects of biochar-immobilization and co-culturing.
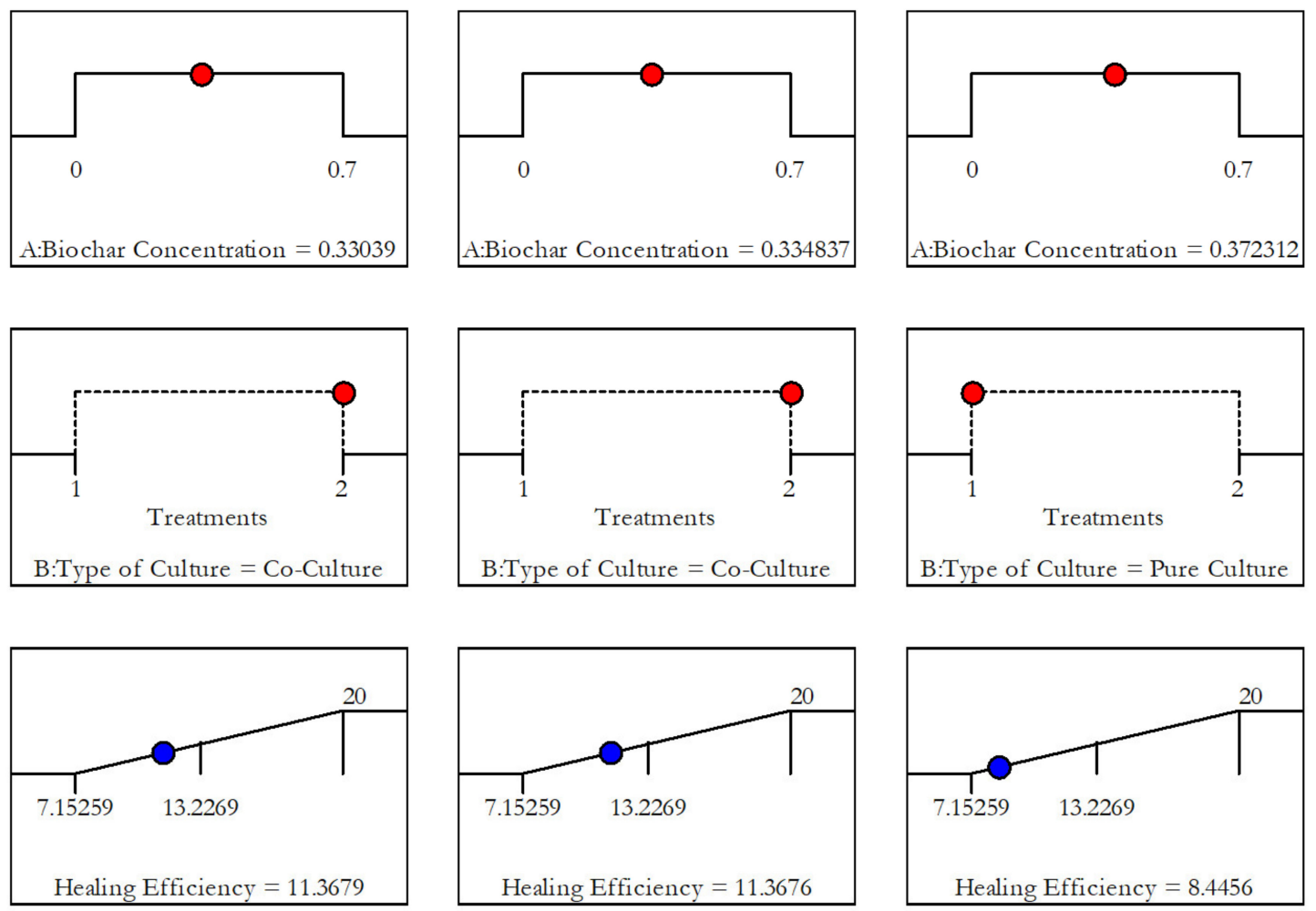

Desirability $=0.328$

Solution 1 out of 3

Desirability $=0.328$

Solution 2 out of 3

Desirability $=0.101$

Solution 3 out of 3

Figure 6. Solutions for optimal healing efficiencies. 


\subsection{Characterization of the Geopolymers and the Mineral Precipitates}

\subsubsection{Confirmation of Samples as Geopolymers}

The bond properties of a geopolymer made in this study were studied through FTIR. Figure 7 shows the plots for the fly ash and a representative geopolymer in the study. Shifting can be observed from $1018 \mathrm{~cm}^{-1}$ in the fly ash to $994 \mathrm{~cm}^{-1}$ in the geopolymer. A shift towards a decreasing wavenumber in this region is an indication that geopolymerization occurred [3,24].

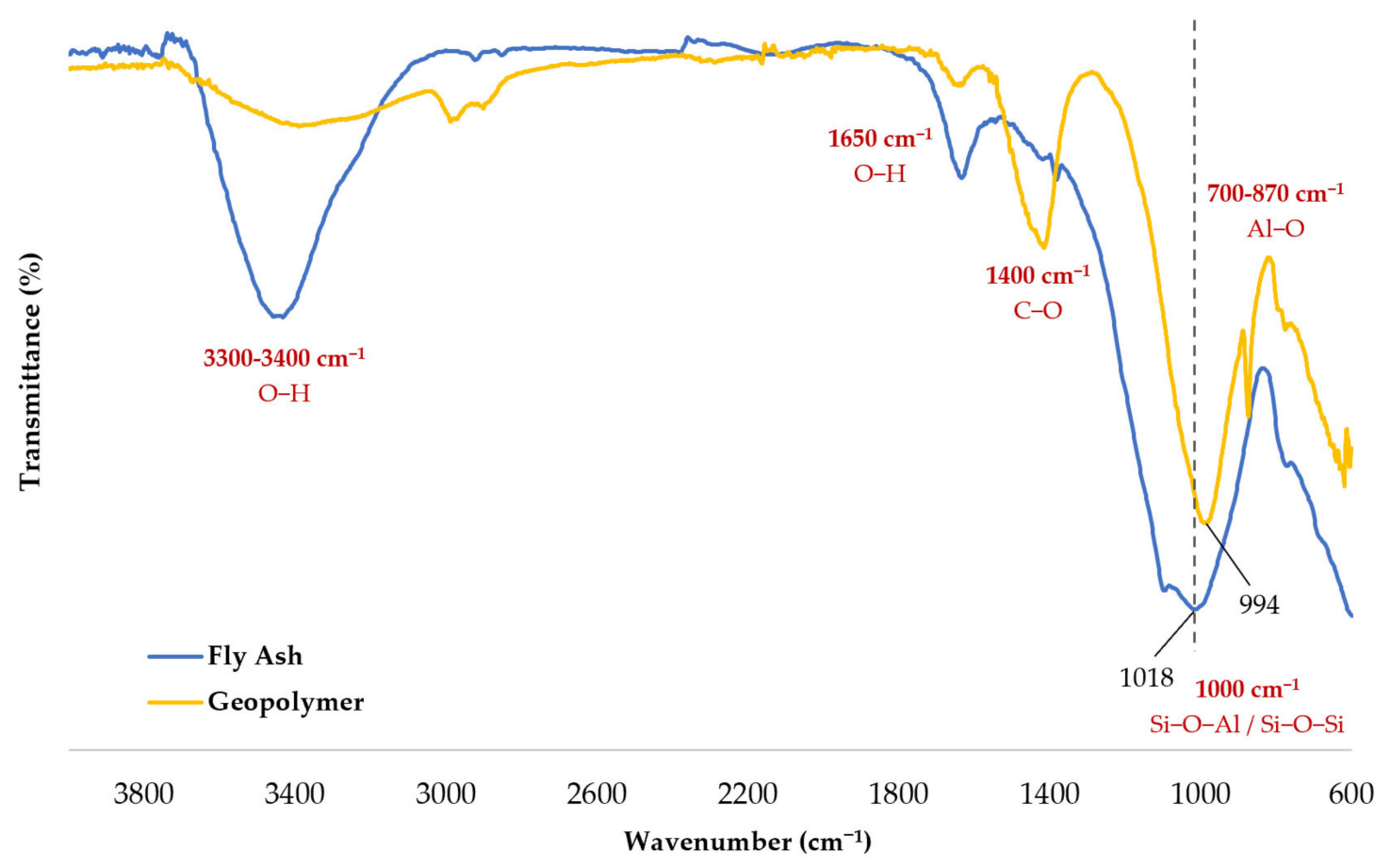

Figure 7. FTIR spectrum for the fly ash and for a control geopolymer.

It can also be seen that the geopolymer has a broad peak around $1000 \mathrm{~cm}^{-1}$. This wavenumber is assigned to Si-O-Al and Si-O-Si vibrations and asymmetric stretching [25]. The band around this area is the most characteristic for geopolymers [26]; thus, this provides crucial evidence that the samples were indeed geopolymers. Second, peaks between $700-870 \mathrm{~cm}^{-1}$ indicate the presence of either tetrahedral or octahedral Al-O groups [27]. This results from variations in the structural reorganization of the reactive species as the geopolymerization process happens [27]. Third, peaks between $3300-3400 \mathrm{~cm}^{-1}$ and around $1650 \mathrm{~cm}^{-1}$ are due to the $\mathrm{O}-\mathrm{H}$ asymmetric stretching, because of the presence of water and silanol groups [25]. Lastly, the peak around $1400 \mathrm{~cm}^{-1}$ comes from the $\mathrm{C}-\mathrm{O}$ groups in the $\mathrm{CO}_{3}{ }^{2-}$ ions, which could have originated from the glass particles in the fly ash, from the added nutrient solution, or from the precipitated minerals.

\subsubsection{Analysis of the Precipitates from Bacterially Induced Mineralization}

The precipitates in the geopolymer cracks were removed and collected, and an SEM analysis was conducted. The images are shown in Figure 8. The presence of organized and well-defined structures in the sample can be seen. EDX analysis of the sample consistently gave an elemental composition of mainly calcium, oxygen, and carbon, as shown in Figure 9. This highly suggests that the precipitated mineral is most likely calcium carbonate $\left(\mathrm{CaCO}_{3}\right)$. However, since the self-healing process essentially involved induced mineralization, the inclusion of impurities in their lattice structure and the lack of control over their mineral formation were expected [10]. This is evident from the subsequent FTIR analysis. 


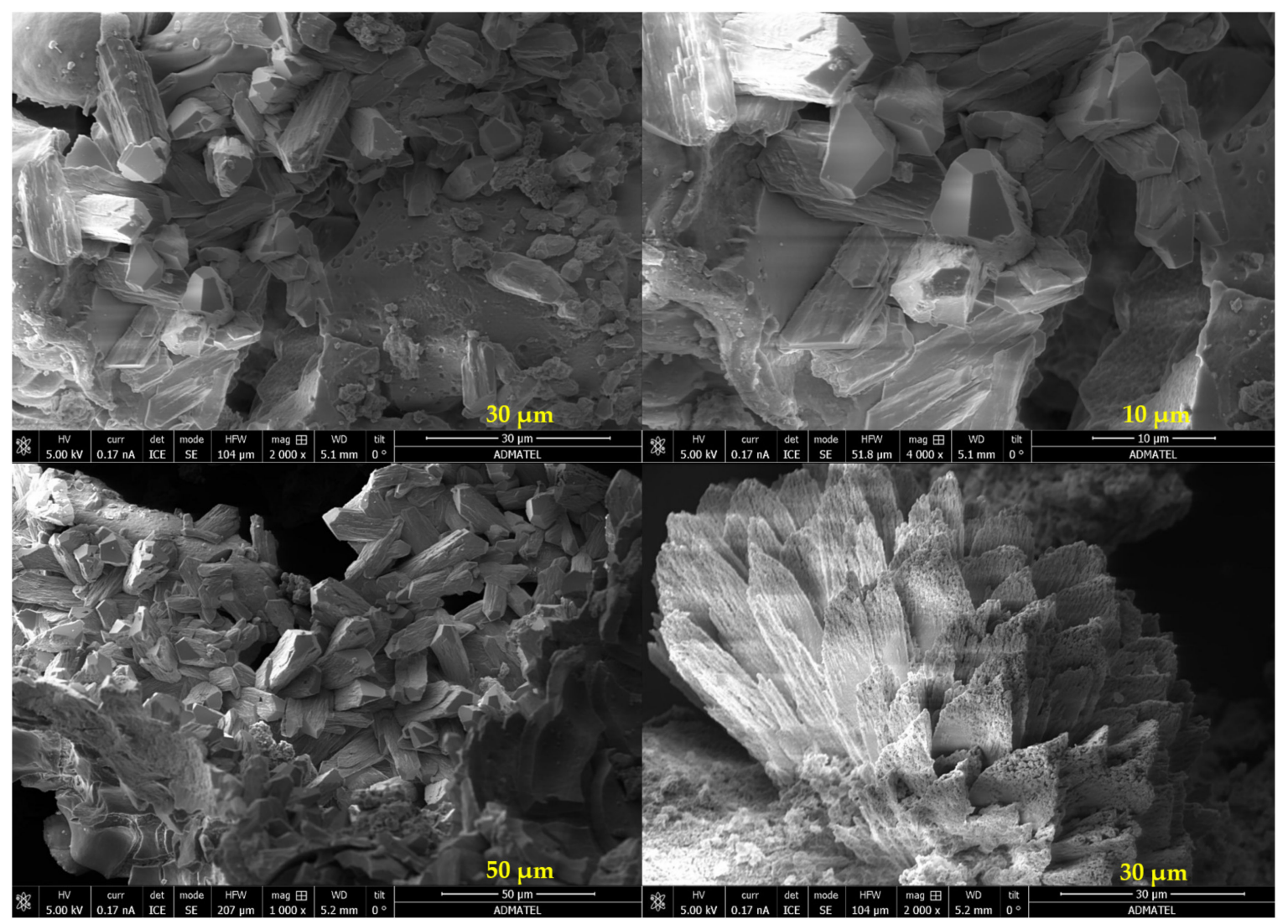

Figure 8. SEM images of the mineral precipitate in the geopolymer cracks.

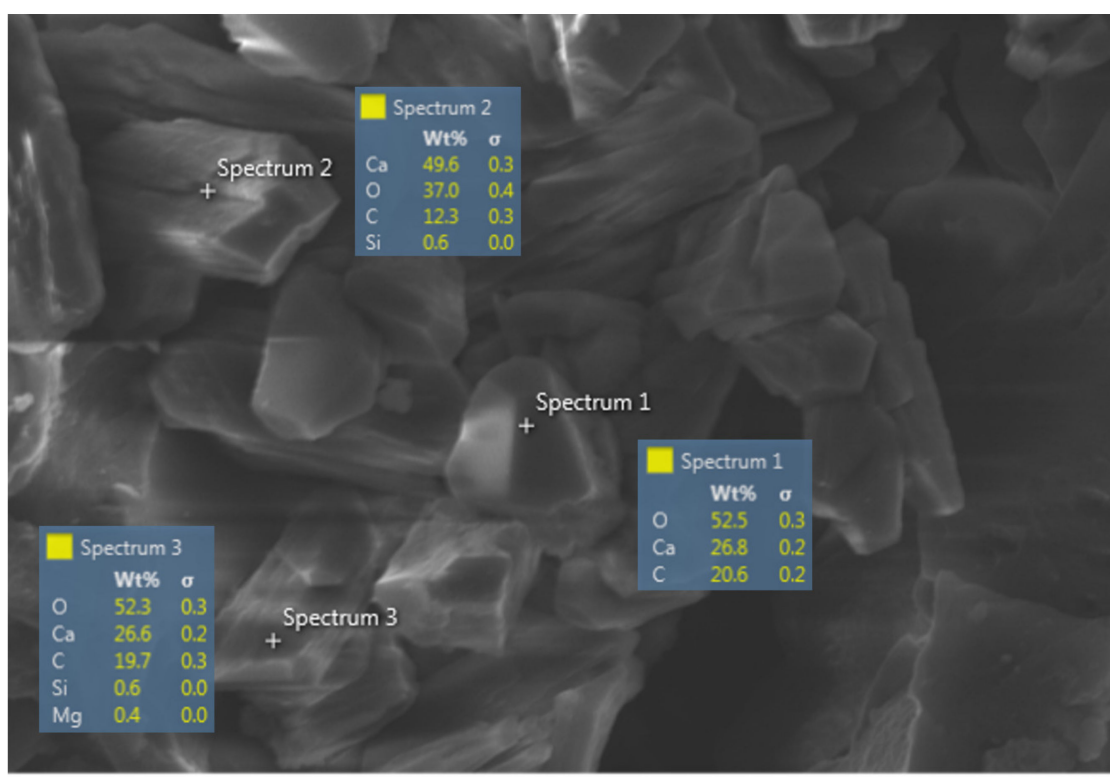

$10 \mu \mathrm{m}$

Figure 9. Elemental composition of the mineral precipitates via EDX analysis.

The FTIR spectrum of the precipitates in the geopolymer cracks is shown in Figure 10. Through data matching, the composition was identified to be mainly calcite $\left(\mathrm{CaCO}_{3}\right)$. The key infrared vibrational bands $\left(v_{1-4}\right)$ of the carbonate ions are shown as well in the figure. It can also be seen in the plot that a broad water band is present. This is an indication that there might be amorphous materials mixed in with the sample. Those materials could be organic ones, such as occluded bacterial cells. As previously 
stated, this is a common phenomenon for bacterially induced/influenced mineralization. Nonetheless, there is enough evidence to say that the geopolymer cracks were sealed with $\mathrm{CaCO}_{3}$.

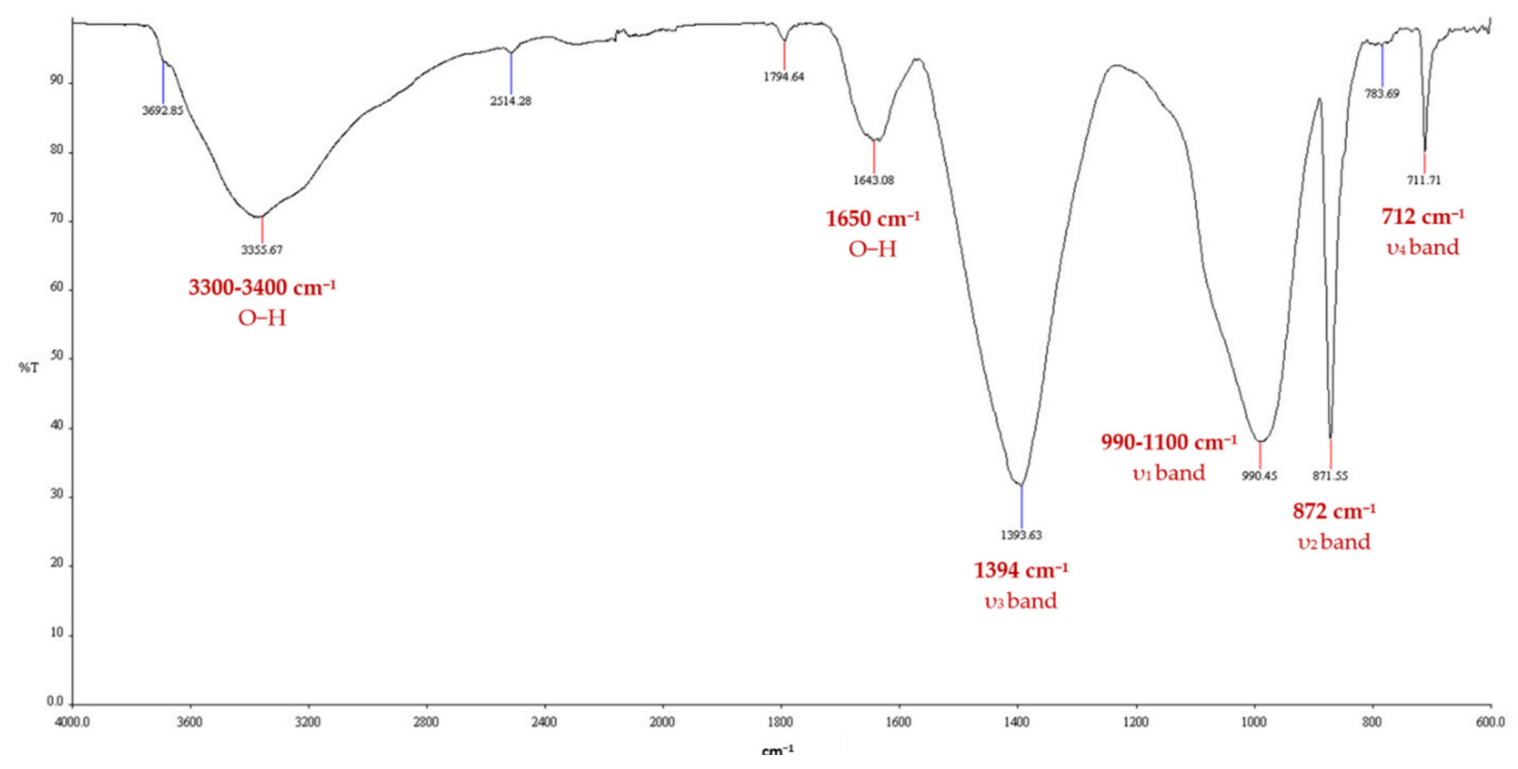

Figure 10. FTIR spectrum of the mineral precipitates in the geopolymer cracks.

\section{Conclusions}

This study presents key findings in developing self-healing biogeopolymers. First, it was determined that both B. subtilis and B. sphaericus demonstrate the potential to act as healing agents for fly ash-based geopolymers. Despite the highly alkaline environment to which they were subjected, they remained viable and were found to facilitate the precipitation of mineral phases. In using B. sphaericus as the healing agent, it was found that co-culturing it with $B$. thuringiensis yields significantly higher healing efficiencies based on ultrasonic pulse velocity measurements of the geopolymers. This could be attributed to the synergistic action of a ureolytic and a non-ureolytic bacteria in the precipitation of $\mathrm{CaCO}_{3}$. The maximum crack width sealed was $0.65 \mathrm{~mm}$ as opposed to only $0.35 \mathrm{~mm}$ when pure cultures were used. Changing the biochar concentration to immobilize the spores, on the other hand, was found to have a weak effect. Despite that, a maximum response was attained when biochar concentration between $0.3-0.4 \mathrm{~g} / \mathrm{mL}$ was used. Through material characterization studies, the deposited precipitates were confirmed to be mostly calcite. With the observed physical sealing of the cracks and the recorded improvements in the mechanical properties of the geopolymers, self-healing could be said to have indeed occurred. Future work will consider using X-ray computed microtomography to visualize and directly measure the extent of self-healing in three dimensions [28,29].

Moving forward, it is recommended to widen the scope of the optimization studies to determine the most optimal conditions for microbial viability and to obtain even higher healing efficiencies that were already attained in past research $[17,18]$. Other researchers can look at using other microorganisms, immobilizing materials, geopolymer precursors, and mix ratios. It is also important to determine whether the weakening effect caused by the added bacteria and nutrients could be compensated by the strengthening effect brought about by self-healing. To gain more insights on the effect of the microorganisms on the strength parameters of the geopolymers, destructive tests are recommended to be used in tandem with non-destructive ones. With these future studies, biogeopolymers may eventually surpass bioconcrete and be gradually used in more practical applications where it can be seen as the concrete solution to a concrete problem of building more sustainable cities and communities. 
Author Contributions: Conceptualization, formal analysis, and funding acquisition, J.Z.S.D. and M.A.B.P.; methodology, J.Z.S.D., A.B.B., M.O.U., and M.A.B.P.; writing-original draft preparation, J.Z.S.D.; writing-review and editing, J.Z.S.D., A.B.B., M.O.U., A.A.S.T., and M.A.B.P.; supervision, A.B.B., M.O.U., A.A.S.T., and M.A.B.P. All authors have read and agreed to the published version of the manuscript.

Funding: This research was funded by the Philippines' Department of Science and Technology-Engineering Research and Development for Technology (DOST-ERDT) and the Philippine Council for Industry, Energy, and Emerging Technology Research and Development (DOST-PCIEERD).

Acknowledgments: The authors acknowledge the Philippine National Collection of Microorganisms (PNCM), the Philippine Rice Research Institute (PhilRice), GNPower Mariveles Coal Plant Ltd. Co, Advanced Device and Materials Testing Laboratory (ADMATEL), Industrial Technology Development Institute (DOST-ITDI), and the DLSU iNano Research Facility for the materials and services provided for this research.

Conflicts of Interest: The authors declare no conflict of interest.

\section{Appendix A. Experimental Design for the Two-Factor Test}

Table A1 shows the experimental design for the bacteria-containing geopolymers in the two-factor test of the study. This was generated using Design Expert by setting the following parameters: (a) pure culture as low level and co-culture as high level for type of culture, and (b) $0 \mathrm{~g} / \mathrm{mL}$ as low level and $0.70 \mathrm{~g} / \mathrm{mL}$ as high level for biochar concentration. The nutrient solution to spore suspension volume ratio was kept constant at 1.5 .

Table A1. Experimental design for the two-factor test.

\begin{tabular}{ccc}
\hline Run & Grams of Biochar per $\mathbf{m L}$ of Spore Suspension & Type of Culture \\
\hline 1 & 0 & Pure Culture \\
\hline 2 & 0.175 & Co-Culture \\
\hline 3 & 0.7 & Pure Culture \\
\hline 4 & 0.35 & Pure Culture \\
\hline 5 & 0.35 & Co-Culture \\
\hline 6 & 0.6055 & Pure Culture \\
\hline 7 & 0.35 & Pure Culture \\
\hline 8 & 0 & Co-Culture \\
\hline 9 & 0.35 & Pure Culture \\
\hline 10 & 0.0945 & Pure Culture \\
\hline 11 & 0.525 & Co-Culture \\
\hline 12 & 0.7 & Co-Culture \\
\hline 13 & 0 & Co-Culture \\
\hline 14 & 0.35 & Co-Culture \\
\hline 15 & 0.7 & Co-Culture \\
\hline
\end{tabular}

Table A2 shows the specifications for the control specimens. These did not contain the spore suspensions, but only distilled water. The nutrient solution to distilled water volume ratio was kept constant at 1.5.

Table A2. Control groups for the two-factor test.

\begin{tabular}{cc}
\hline Control Group & Grams of Biochar per $\mathbf{m L}$ of Distilled Water \\
\hline Con-A & 0 \\
\hline Con-B & 0.175 \\
\hline Con-C & 0.525 \\
\hline Con-D & 0.70 \\
\hline
\end{tabular}




\section{Appendix B. Schaeffer-Fulton Stains}

A comparison of the Schaeffer-Fulton stains directly from an agar plate and from the spore suspensions is shown in Figure A1. It can be seen that the spores in the prepared suspensions were not associated with red vegetative cells. This indicates that the spores obtained had sufficiently matured and that the method of preparing them was satisfactory. The appearance of the green stain in the spores was due to the malachite green being forced into the endospores by heat. Upon the use of the decolorizer, the green stain was washed out from the cell walls, but not from the spore walls. The use of safranin then allowed the vegetative cells to be viewed as red.

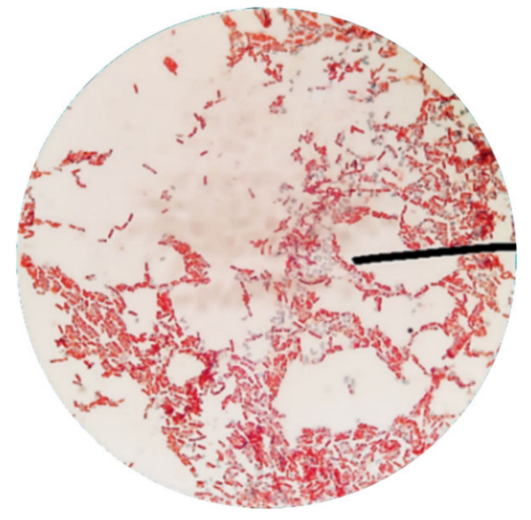

(a)

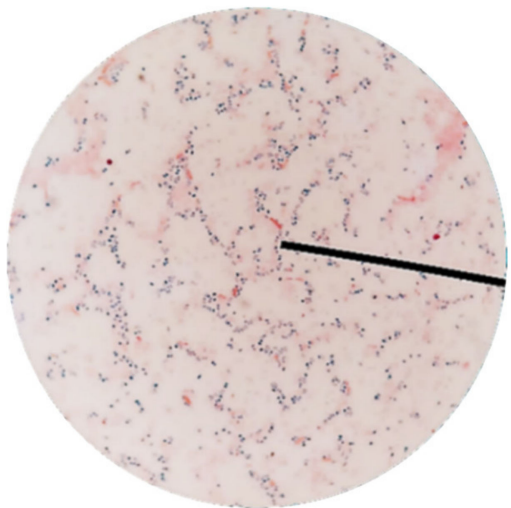

(b)

Figure A1. Schaeffer-Fulton stains under an optical microscope: (a) directly from an agar plate; (b) from the spore suspensions.

\section{Appendix C. Analysis of Variance for the Two-Factor Test}

Table A3 shows the ANOVA for the results of the two-factor test. It shows that changes in the biochar concentration did not strongly affect the healing efficiencies of the geopolymers, but the use of co-cultures does. The analysis also shows that the model generated by the software is significant.

Table A3. Analysis of variance for the two-factor test

\begin{tabular}{cccccc}
\hline Source & Sum of Squares & Degree of Freedom & Mean Square & $F$-Value & $p$-Value \\
\hline Model & 37.73 & 4 & 9.43 & 5.63 & 0.0122 \\
\hline $\begin{array}{c}\text { A-Biochar } \\
\text { Concentration }\end{array}$ & 0.0017 & 1 & 0.0017 & 0.0010 & 0.9751 \\
\hline B-Type of Culture & 31.28 & 1 & 31.28 & 18.68 & 0.0015 \\
\hline $\mathrm{AB}$ & 0.3863 & 1 & 0.3863 & 0.2307 & 0.6413 \\
\hline $\mathrm{A}^{2}$ & 10.44 & 1 & 10.44 & 6.23 & 0.0316 \\
\hline Residual & 16.74 & 10 & 1.67 & & \\
\hline Lack of Fit & 9.99 & 5 & 2.00 & 1.48 & 0.3391 \\
\hline Pure Error & 6.75 & 5 & 1.35 & & \\
\hline Cor Total & 54.47 & 14 & & & \\
\hline
\end{tabular}

Figure A2 illustrates that the residual points lie close to the normal distribution line; thus, they follow a normal distribution. Furthermore, no other definite patterns can be observed from their plot. With that, no transformation of data was necessary. 


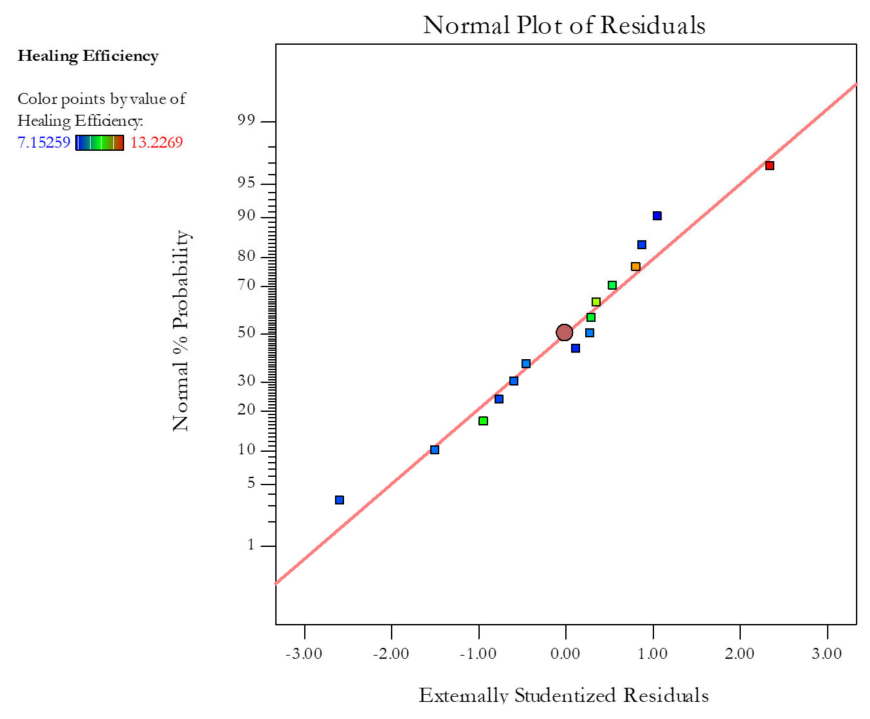

Figure A2. Normal plot of the residuals.

Figure A3 depicts the residuals versus the ascending predicted response values. Because the plot shows a random scatter and not an expanding variance, often identified by a "megaphone $(<)$ " pattern, the assumption of constant variance was satisfied.

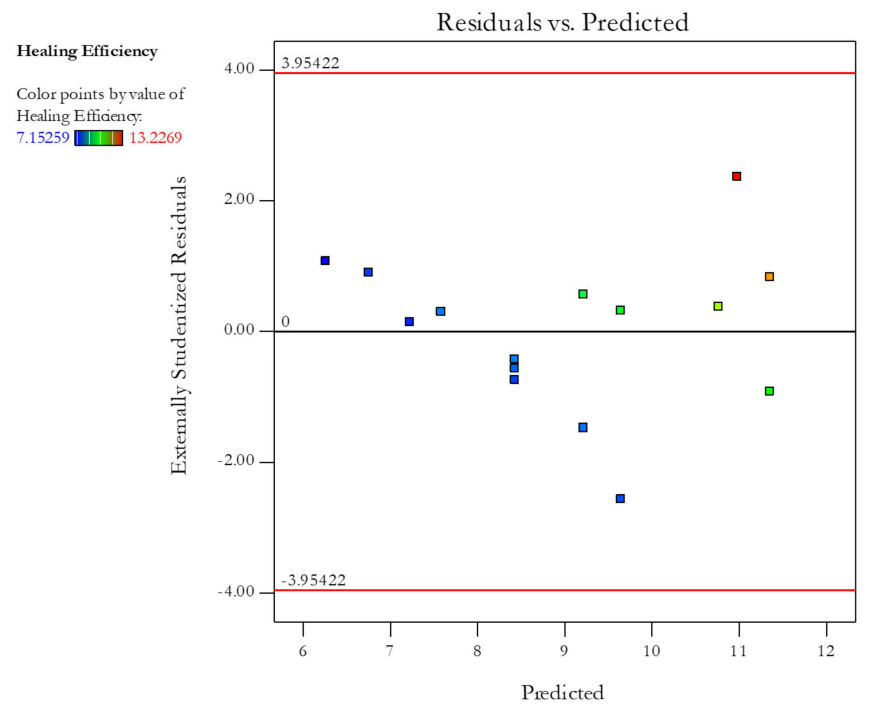

Figure A3. Plot of the residuals versus the predicted response values.

Figure A4 shows that the plots of the residuals versus biochar concentration and residuals versus type of culture show random scatter. This indicates that there is no systematic contribution of an independent factor not accounted for by the model. 


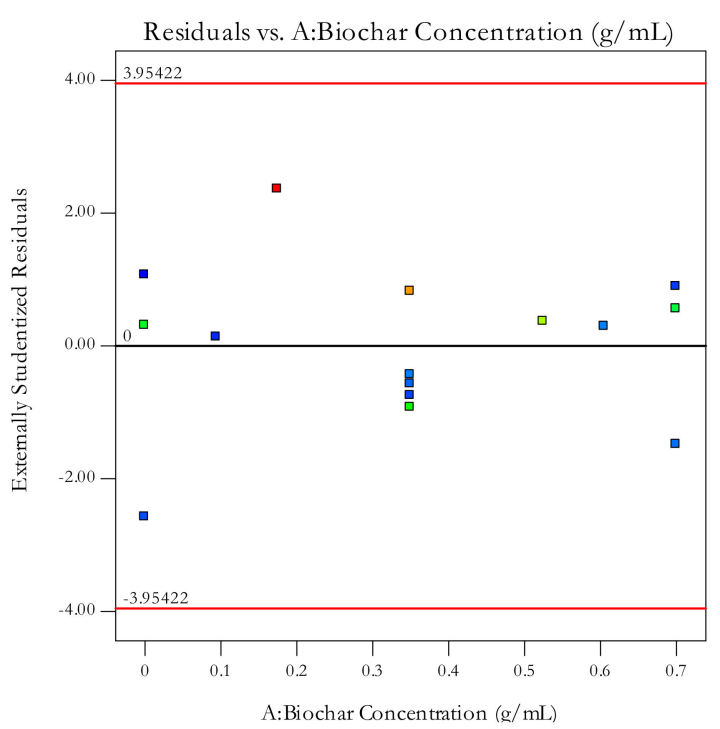

(a)

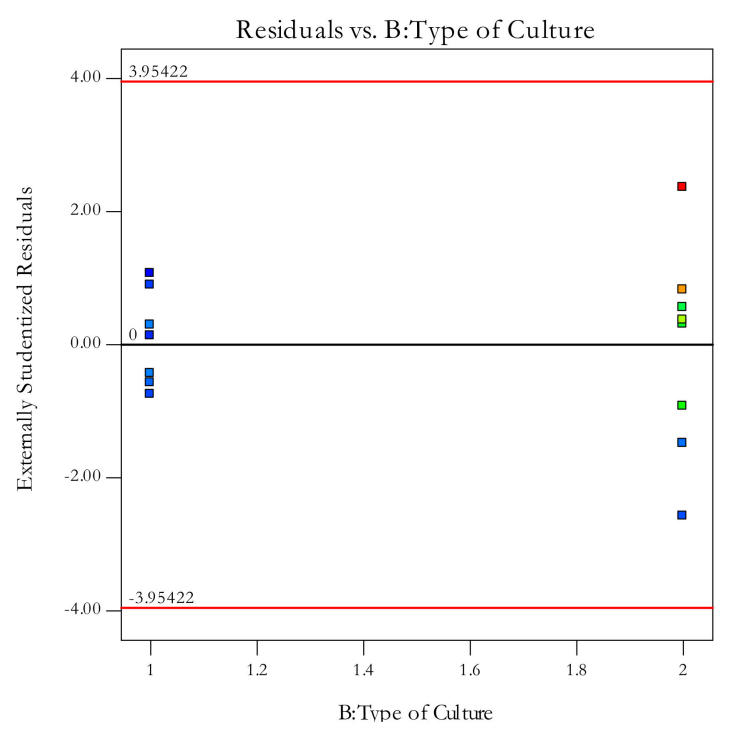

(b)

Figure A4. Plots of the residuals versus (a) biochar concentration and (b) type of culture.

\section{References}

1. Burciaga-Díaz, O.; Magallanes-Rivera, R.X.; García, J.E. Alkali-activated slag-metakaolin pastes: Strength, structural, and microstructural characterization. J. Sustain. Cem. Mater. 2013, 2, 111-127. [CrossRef]

2. Chi, M.-C.; Chang, J.-J.; Huang, R. Strength and drying shrinkage of alkali-activated slag paste and mortar. Adv. Civ. Eng. 2012, 2012, 1-7. [CrossRef]

3. Tigue, A.A.S.; Malenab, R.A.; Dungca, J.R.; Yu, D.E.C.; Promentilla, M.A.B. Chemical stability and leaching behavior of one-part geopolymer from soil and coal fly ash mixtures. Minerals 2018, 8, 411. [CrossRef]

4. Malenab, R.A.; Ngo, J.P.S.; Promentilla, M.A.B. Chemical treatment of waste abaca for natural fiber-reinforced geopolymer composite. Materials 2017, 10, 579. [CrossRef] [PubMed]

5. Khaliq, W.; Ehsan, M.B. Crack healing in concrete using various bio influenced self-healing techniques. Constr. Build. Mater. 2016, 102, 349-357. [CrossRef]

6. Luo, J.; Chen, X.; Crump, J.; Zhou, H.; Davies, D.G.; Zhou, G.; Zhang, N.; Jin, C. Interactions of fungi with concrete: Significant importance for bio-based self-healing concrete. Constr. Build. Mater. 2018, 164, 275-285. [CrossRef]

7. Skinner, H.; Ehrlich, H. Biomineralization. In Treatise on Geochemistry; Elsevier BV: Berlin, Germany, 2014; pp. 105-162.

8. Benzerara, K. Biomineralization. In Encyclopedia of Astrobiology; Springer Science and Business Media LLC: Berlin/Heidelberg, Germany, 2011; pp. 197-198.

9. Dhami, N.K.; Reddy, M.S.; Mukherjee, A. Biomineralization of calcium carbonates and their engineered applications: A review. Front. Microbiol. 2013, 4, 314. [CrossRef] [PubMed]

10. Frankel, R. Biologically induced mineralization by bacteria. Rev. Miner. Geochem. 2003, 54, 95-114. [CrossRef]

11. Wang, J.; Snoeck, D.; Van Vlierberghe, S.; Verstraete, W.; De Belie, N. Application of hydrogel encapsulated carbonate precipitating bacteria for approaching a realistic self-healing in concrete. Constr. Build. Mater. 2014, 68, 110-119. [CrossRef]

12. Vijay, K.; Murmu, M.; Deo, S.V. Bacteria based self healing concrete-A review. Constr. Build. Mater. 2017, 152, 1008-1014. [CrossRef]

13. Gupta, S.; Kua, H.W.; Pang, S.D. Healing cement mortar by immobilization of bacteria in biochar: An integrated approach of self-healing and carbon sequestration. Cem. Concr. Compos. 2018, 86, 238-254. [CrossRef]

14. Van Mullem, T.; Gruyaert, E.; Caspeele, R.; De Belie, N. First large scale application with self-healing concrete in belgium: Analysis of the laboratory control tests. Materials 2020, 13, 997. [CrossRef] [PubMed]

15. Jadhav, U.U.; Lahoti, M.; Chen, Z.; Qiu, J.; Cao, B.; Yang, E.-H. Viability of bacterial spores and crack healing in bacteria-containing geopolymer. Constr. Build. Mater. 2018, 169, 716-723. [CrossRef] 
16. Wulandari, K.D.; Ekaputri, J.J.; Triwulan, N.; Fujiyama, C.; Setiamarga, D. Effects of microbial agents to the properties of fly ash-based paste. In Proceedings of the MATEC Web of Conferences; EDP Sciences: Les Ulis, France, 2018; Volume 195, p. 01012.

17. Chatterjee, A.; Chattopadhyay, B.; Mandal, S. Bacterium amended $100 \%$ fly ash geopolymer. In Proceedings of the International Conference on Sustainable Materials and Structures for Civil Infrastructures (SMSCI2019), Madhya Pradesh, India, 4-15 March 2019; AIP Publishing: New York, NY, USA, 2019; Volume 2158, p. 020013.

18. Wulandari, K.D.; Ekaputri, J.J.; Triwulan, N.; Kurniawan, S.B.; Primaningtyas, W.E.; Abdullah, S.R.S.; Ismail, N.I.; Imron, M.F. Effect of microbes addition on the properties and surface morphology of fly ash-based geopolymer paste. J. Build. Eng. 2021, 33, 101596. [CrossRef]

19. Son, H.M.; Kim, H.Y.; Park, S.; Lee, H. Ureolytic/Non-ureolytic bacteria co-cultured self-healing agent for cementitious materials crack repair. Materials 2018, 11, 782. [CrossRef]

20. Arafa, S.A.; Ali, A.Z.M.; Awal, A.A.; Loon, L.Y. Optimum mix for fly ash geopolymer binder based on workability and compressive strength. In IOP Conference Series: Earth and Environmental Science; IOP Publishing: Bristol, UK, 2018; Volume 140, p. 012157.

21. Nain, N.; Surabhi, R.; Yathish, N.; Krishnamurthy, V.; Deepa, T.; Tharannum, S. Enhancement in strength parameters of concrete by application of Bacillus bacteria. Constr. Build. Mater. 2019, 202, 904-908. [CrossRef]

22. Bacterial Concrete-A Sustainable Solution for Concrete Maintenance. Int. J. Innov. Technol. Explor. Eng. 2019, 8, 227-232. [CrossRef]

23. Gorovtsov, A.V.; Minkina, T.M.; Mandzhieva, S.S.; Perelomov, L.V.; Soja, G.; Zamulina, I.V.; Rajput, V.D.; Sushkova, S.N.; Mohan, D.; Yao, J. The mechanisms of biochar interactions with microorganisms in soil. Environ. Geochem. Health 2020, 42, 2495-2518. [CrossRef]

24. Kalaw, M.E.; Culaba, A.B.; Hinode, H.; Kurniawan, W.; Gallardo, S.M.; Promentilla, M.A.B. Optimizing and characterizing geopolymers from Ternary Blend of Philippine Coal Fly Ash, coal bottom ash and rice hull ash. Materials 2016, 9, 580. [CrossRef]

25. Khan, M.I.; Azizli, K.A.; Sufian, S.; Siyal, A.A.; Man, Z. Sodium silicate free geopolymer as coating material: Adhesion to steel. In Proceedings of the 1st International Electronic Conference on Materials, 26 May-10 June 2014; MDPI: Basel, Switzerland, 2014.

26. Rosas-Casarez, C.; Arredondo-Rea, S.; Gómez-Soberón, J.; Alamaral-Sánchez, J.; Corral-Higuera, R.; Chinchillas-Chinchillas, M.; Acuña-Agüero, O. Experimental study of XRD, FTIR and TGA techniques in geopolymeric materials. Int. J. Adv. Comput. Sci. Its Appl. 2014, 4, 25-30.

27. Kumar, S.; Kumar, R. Mechanical activation of fly ash: Effect on reaction, structure and properties of resulting geopolymer. Ceram. Int. 2011, 37, 533-541. [CrossRef]

28. Ruan, S.; Qiu, J.; Weng, Y.; Yang, Y.; Yang, E.-H.; Chu, J.; Unluer, C. The use of microbial induced carbonate precipitation in healing cracks within reactive magnesia cement-based blends. Cem. Concr. Res. 2019, 115, 176-188. [CrossRef]

29. Suleiman, A.R.; Nelson, A.J.; Nehdi, M.L. Visualization and quantification of crack self-healing in cement-based materials incorporating different minerals. Cem. Concr. Compos. 2019, 103, 49-58. [CrossRef]

Publisher's Note: MDPI stays neutral with regard to jurisdictional claims in published maps and institutional affiliations.

(C) 2020 by the authors. Licensee MDPI, Basel, Switzerland. This article is an open access article distributed under the terms and conditions of the Creative Commons Attribution (CC BY) license (http://creativecommons.org/licenses/by/4.0/). 